University of California, Hastings College of the Law UC Hastings Scholarship Repository

Faculty Scholarship

2004

\title{
What the Supreme Court Should Do: Save Sentencing Reform, Gut the Guidelines
}

Aaron J. Rappaport

UC Hastings College of the Law, rappapor@uchastings.edu

Follow this and additional works at: http://repository.uchastings.edu/faculty_scholarship

Part of the Criminal Law Commons, and the Criminal Procedure Commons

\section{Recommended Citation}

Aaron J. Rappaport, What the Supreme Court Should Do: Save Sentencing Reform, Gut the Guidelines, 17 Fed. Sent. R. 46 (2004). Available at: http://repository.uchastings.edu/faculty_scholarship/665

This Article is brought to you for free and open access by UC Hastings Scholarship Repository. It has been accepted for inclusion in Faculty Scholarship by an authorized administrator of UC Hastings Scholarship Repository. For more information, please contact marcusc@uchastings.edu. 


\title{
Faculty Publications \\ UC Hastings College of the Law Library
}

\author{
Author: Aaron J. Rappaport \\ Source: $\quad$ Federal Sentencing Reporter \\ Citation: 17 Fed. Sent. R. 46 (2004). \\ Title: What the Supreme Court Should Do: Save Sentencing Reform, Gut the \\ Guidelines
}

Originally published in FEDERAL SENTENCING REPORTER. This article is reprinted with permission from FEDERAL SENTENCING REPORTER and University of California Press; Vera Institute of Justice. 


\section{What the Supreme Court Should Do: Save Sentencing Reform, Gut the Guidelines}

The legal community has been deeply troubled about the likely outcome of the Supreme Court's rulings in Booker and Fanfan. Commentators appear to be coalescing around two opposing positions. Both groups expect the decisions to be highly unsatisfying.

One group can see no plausible distinction between the sentencing scheme struck down in Blakely and the federal sentencing guidelines. As a result, they expect the Court to find the guidelines unconstitutional, which could mean the end of sentencing reform in America. The second group believes that the Court will decline to overturn the guidelines on pragmatic grounds, fearing the havoc such a decision would cause. This group expects the Court to distinguish the federal system on the grounds that Blakely applies to statutory, but not administrative, sentencing schemes. ${ }^{I}$ The problem for this group is that no one seems able to explain why that line is justified, which means the Court will elevate an arbitrary distinction to the level of constitutional significance.

Both of these positions share the same basic concern, that no principled distinction can be made between an administrative rulemaking system and a statutory one. In this paper, I argue that this conclusion is mistaken for a simple reason. It fails to recognize that a principled rationale for the Supreme Court's Apprendi and Blakely decisions can be identified, a rationale that provides a basis for distinguishing the two kinds of sentencing regimes, at least in some circumstances.

At the same time, this analysis does not imply that the federal sentencing system necessarily withstands constitutional scrutiny. Rather, the more nuanced understanding of Blakely and Apprendi generates a specific test for evaluating whether administrative schemes survive review. It is a test the federal sentencing guidelines may not pass, at least absent significant restructuring.

This analysis provides a preliminary attempt to ground the Apprendi and Blakely decisions on deeper constitutional values. It does not aspire to be comprehensive and, in the press of time, the discussion passes over some important issues quickly. Nonetheless, my hope is that this effort will encourage further debate about the logic of the Court's decisions.

The analysis is briefly sketched out in the following two parts. Part One examines the core principle that lies implicit in the Blakely and Apprendi decisions. Part Two looks at the implications of that principle for the federal guideline system.

\section{The Logic of Apprendi and Blakely}

How should Blakely and Apprendi be interpreted? It seems difficult to read those cases as being compelled by the text or original intent of the Sixth Amendment or the Due Process clause. At best, the relevant constitutional text is ambiguous, at worst it offers no support for the Court's holding. Thus, if Blakely and Apprendi are thought to be legitimate precedent, they must be viewed through a different interpretive lens. They must be viewed as illustrations of what might be called, for want of a better phrase, common law constitutional decisionmaking. ${ }^{2}$

Under such an approach, the Court seeks, in a step by step manner, to develop a constitutional rule that promotes the nation's core values and goals. Often, in common law rulemaking, the underlying rationale of a group of decisions is obscure at first even to the Justices. However, the hope is that over time a coherent and appealing rule will emerge from the mix of decisions. If such a rule can be identified, the Court must then determine whether the rule promotes social welfare and fundamental fairness. If it passes muster, the rule will serve as a standard for deciding future cases.

This interpretive approach raises the obvious question: Do the Court's decisions in Apprendi and Blakely embody an appealing rule or principle? Many commentators have concluded that they do not, that no logic underlies the court's precedent in this area. ${ }^{3}$ Before we dismiss the entire body of law, however, it is worth exploring in greater detail whether a justified principle can be discovered. Several possibilities immediately spring to mind.

One possible rationale for the decisions was mentioned by Justice Kennedy in his Blakely dissent. Kennedy suggested that the Court's decision reflects a critical view of the judges' role at sentencing, and specifically its role in identifying facts that trigger statutory sentencing increases. ${ }^{4}$ If such facts are to be identified, the argument goes, they must be found by a jury at trial.

Does this principle help explain the Court's decisions in Apprendi and Blakely? No, it does not. After all, the Court's rulings permit a trial court to make sentencing

Federal Sentencing Reporter, Vol. I7, Issue I, pp. 46-50, ISSN 1053-9867, electronic ISSN 1533-8363. (C) 2004 Vera Institute of Justice. All rights reserved. Please direct all requests for permission to photocopy or reproduce article content through the University of California Press's Rights and Permissions website, at www.ucpress.edu/journals/rights.htm. 
decisions in an indeterminate sentencing scheme, a scheme in which judges have even greater discretion to determine the ultimate sentences than in determinate systems. Thus, it does not make sense to say that the core holding of these cases is a distrust of judicial sentencing power.

Kennedy's dissent does, however, point us in the right direction, in the sense that Blakely and Apprendi can be viewed as judgments about institutional roles. Rather than viewing the decisions as judgments about judicial power, a more plausible approach is to view them as reflecting a profound distrust of the legislature's role in sentencing policy. The idea, simply stated, is that when the legislature identifies a factor as being relevant to the sentencing maximum, and assigns a weight to that factor, then higher procedural protections must apply.

A natural question is why such a distrust should be part of our legal firmament. The answer is not difficult to see. Such a distrust is consistent with both the structure of our constitutional system and the protections embodied in specific provisions of the constitution, such as the Due Process clause.

Perhaps most obviously, the core structure of our constitutional system is based on a distrust of legislative power, particularly where that power is used to infringe on individual liberty. That distrust reflects a historic fear of the tyranny of the majority. As Mill wrote, the strongest of all the arguments against public interference with individual liberty "is that, when it does interfere, the odds are that it interferes wrongly and in the wrong place." 5 Those dangers are particularly acute in the criminal justice field, where public passions may lead to legislative overreaching or ill-considered rules. ${ }^{6}$

The Court's interpretation of the Due Process clause lends further credence to this view.? The clause recognizes that social welfare requires a balancing of private and public interests. ${ }^{8}$ Where core liberties are at stake, the Due Process clause imposes significant protections against legislative overreaching - requiring, for example, compelling justifications for state action. Needless to say, in the sentencing field, the most essential human liberties are at stake, which explains why protections from legislative abuse are especially important in this context. ${ }^{9}$

The basic distrust of legislative power does not extend with the same force to judicial decisionmaking. The reason reflects the judiciary's different institutional structure and perspective. Because federal judges enjoy life tenure, they are more insulated from political pressures and, hence, the danger of overreaching is diminished. ${ }^{\circ}$ Moreover, because the sentencing judge must confront the individual defendant in the case, there is greater opportunity to see the individual as a human being, not an abstraction. Both factors mean that the judiciary will likely be more sensitive to individual interests in deciding cases and imposing punishments. Indeed, the judiciary's historic role is to protect individual liberty against legislative overreaching. ${ }^{\text {.I }}$ The Court' jurisprudence assumes that constitutional protections that apply to legislative rulemaking need not apply to the exercise of judicial power. ${ }^{\text {I2 }}$

The question that must be addressed next is what sort of sentencing rule might vindicate this core distrust of legislative power in the sentencing arena. In Apprendi and Blakely, the Court offered an initial answer. Apprendi dealt with legislation that increased the statutory maximum upon specific judicial findings. Blakelyinvolved legislation that increased the maximum presumptive sentence that a defendant might receive, based on specific factual findings by the court. Both kinds of legislation potentially expose the defendant to heightened punishment, and so raise concerns about legislative abuse.

The rule adopted in Blakely and Apprendi is a plausible response to these concerns. In those cases, the Court imposed strict procedural burdens on the government whenever legislation provides for an increase in the permissible or presumptive maximum sentences based on a factual finding. Specifically, the increased sentence will be authorized only if the government proves the triggering facts at trial.

This procedural rule will have several beneficial effects. First, the ruling may cause the legislature to pause before enacting these provisions, since the statutes would likely increase the cost of already unwieldy trials. Ideally, Congress would limit the provisions to those factors that appear most essential to promoting social goals. Second, the rule forces prosecutors to prove the triggering facts under the strictest standard of proof, ensuring that the maximum sentence is not increased without strong evidentiary support. Third, and perhaps most importantly, the approach authorizes the jury to make the necessary findings of fact. In doing so, the constitutional rule gives the jury an opportunity to nullify overly-severe laws at trial. ${ }^{13}$ In this sense, the rule helps promote the jury's fundamental "liberty protecting" role. ${ }^{14}$

Of course, the modest procedural burden imposed by the Court may prove ineffectual. Despite the restrictions, the legislature may continue to enact excessively severe legislation that raises the statutory maximum, ignoring the increased costs of jury fact-finding. The jury, in turn, might implement the harsh sentencing rules without reflection, failing to fulfill its responsibility as a defender of liberty. If these events occur, further remedial steps by the Court may be necessary. But as a first step in addressing legislative abuse, the rule adopted by the Court in Apprendi and Blakely is not an implausible one.

The principle that underlies these cases makes intuitive sense, and it is consistent with the constitutional structure and the text of the Due Process clause. It is not, however, consistent with all Court precedent. Specifically, it is not consistent with the Court's decision in Harris, where the Court held that constitutional protections do not apply to mandatory minimum statutes. The problem with this ruling is that mandatory minimum legislation seems to implicate serious concerns about legislative overreaching. 
As Justice Thomas wrote in his Harris dissent, a mandatory minimum typically has a far greater impact on a defendant's sentence than a statutory maxima. ${ }^{15}$ Mandatory minimums often effectively determine the sentence that the defendant will receive. Thus, if constitutional limitations on legislative power are necessary in the sentencing field, those protections would seem critical in the case of mandatory minimum statutes, as well.

The implications of this analysis is that the Court should reconsider and reverse its holding in Harris. ${ }^{16}$ Overturning Harris would extend the benefits of the Apprendi and Blakely rulings to this critical context. It would impose the highest standard of proof for facts triggering mandatory minimum sentences. It would discourage the legislature from enacting those statutes in the first place. And it would permit the jury to serve as a check against legislative abuse. Reversing Harris, in short, would help establish an institutional structure for sentencing that is more consistent with a core distrust of legislature power in the sentencing realm.

\section{Implications for the United States Sentencing Guidelines}

The preceding analysis identifies a plausible and appealing rationale for the Court's decisions in Apprendi and Blakely (though not Harris), a rationale that justifies imposing procedural restrictions on legislative sentencing. Understanding the rationale helps to clarify whether similar restrictions should be applied to administrative rulemaking in the sentencing field. The answer is that such protections should apply if a sentencing commission poses the same dangers as a legislature. And that depends primarily on a "functional analysis" - an analysis of the institutional roles and biases of the Commission. ${ }^{17}$ Specifically, this approach requires an assessment of whether the Commission poses the same danger of overreaching the same threat to individual liberty - as the legislature.

This analysis turns on the same factors that underlie the constitutional distrust of the legislative power. Two considerations seem particularly relevant. First, we noted that the susceptibility of the legislature to majoritarian passions is a key factor in justifying restrictions on legislative fact finding. Whether or not the Commission faces the same problems depends in part on its institutional structure. Is the Commission structured in a way that ensures its institutional independence? Or is it structured in a way that makes it highly vulnerable to political pressure and legislative meddling?

Second, we noted that the judiciary's direct exposure to the defendant makes the institution more sensitive to the effects of excessive punishment. The legislature's distance from the human subject - its tendency to view the defendant as an abstraction - makes it a particularly dangerous organ of sentencing policy. The question again is whether the Commission is structured in a way that ensures it will take into account the concrete human impact of its rules.
The analysis would be an easier one if the U.S. Sentencing Commission were comprised solely of federal judges (say, as a body of the Judicial Conference), and if its sentencing choices were not subject to legislative interference. In that case, it would plainly have a degree of insulation from political pressures. Moreover, a Commission comprised of active judges would have first-hand familiarity with the effects of its rules on offenders.

The issue is far less clear in the case of the U.S. Sentencing Commission. On one hand, certain aspects of the Commission's organizational structure encourage a degree of political independence, such as the requirement that Commissioners be appointed to six-year staggered terms. But on the other hand, there are many reasons to doubt the Commission's ability to act independently of political pressures.

As an initial matter, the Commissioners are all nominated through the ordinary political channels. In establishing the Commission, Congress made no effort to ensure a neutral appointment process, such as through the establishment of a bipartisan review board to nominate Commissioners. Moreover, under current law, no more than three members of the Commission may be federal judges. In theory, the entire Commission could be made of non-judges.

The history of the sentencing guidelines - well documented in the pages of the Federal Sentencing Reporter - raises further doubts about the Commission's institutional ability to withstand political pressures. Since its founding, the Commission has been subject to widespread criticism for its political responsiveness. ${ }^{18}$ Justice Scalia's warning that the Commission represents a "junior varsity legislature" appears to be sadly prescient.

Finally, as Steven Chanenson argues, recent statutory changes have undermined the Commission's independence in further and dramatic ways. ${ }^{19}$ Specifically, in April 2003, Congress enacted the so-called PROTECT Act. ${ }^{20}$ Chanenson observes that the Act blurs the lines between administrative and legislative rulemaking. In addition to reducing the number of judges that may serve on the Commission, the Act directly "amended guidelines to [Congress'] own specifications," while "prohibit[ing] the Sentencing Commission from creating certain new guidelines." of the Federal Sentencing Guidelines have been enacted directly by Congress." ${ }^{22}$

These concerns raise serious questions about whether the Commission, as it is presently structured, can withstand constitutional review under the principle implicit in Blakely and Apprendi. ${ }^{23}$ At the same time, the analysis presented here does not mean that the Court has created an insurmountable obstacle to sentencing reform in the future. So long as the Congress establishes a Commission with sufficient guarantees of independence, an administrative rulemaking system will survive review. If this analysis is followed, Blakely might not mark the end of 
sentencing reform. It might instead mark the beginning of real sentencing reform, the kind of reform commentators have long been waiting to see.

\section{Notes}

1 Several circuit courts have upheld the federal guidelines on these grounds. United States v. Reese 2004 WL 1846076 (11th Cir. Sept 2, 2004) (refusing to apply Blakely to federal guidelines); United States v. Hammoud, 2004 WL 2005622 (4th Cir. Sept. 8, 2004) (same); United States v. Koch, 2004 WL 189930 (6th Cir. Aug. 26, 2004) (suggesting that "differences between the sentencing provisions at issue in Blakely and the Federal Sentencing Guidelines may well have constitutional significance"); United States v. Pineiro, 377 F.3d 464 (5th Cir. 2004). See also United States v. Mincey, 350 F.3d 100 (2d Cir. 2004) (refusing to apply Blakely to guidelines pending Supreme Court decisions in Booker and Fanfan).

2 See generally David Strauss, Common Law Constitutional Interpretation, 63 U.CHI. L. REv. 877 (1996).

3 See, e.g., Blakely v. Washington, 124 S. Ct. 2531 (June 24, 2004) (O'Connor dissenting) (" $[1]$ t is difficult for me to discern what principle besides doctrinaire formalism actually motivates today's decision."); Frank Bowman, Train Wreck? Or Can the Federal Sentencing Guidelines Be Saved? A Plea for Rapid Reversal of Blakely v. Washington, 42, Crim. L. Rev.-_(forthcoming 2004) (The Court "can distinguish the federal sentencing system ... on the, frankly, specious, ground that Washington's sentencing ranges were set by statutes.... However, to do so would ... expose the Court to ridicule for indulging in transparent evasion of precedent on which the ink is scarcely dry. ...").

4 Blakely, 124 S. Ct. at 2551 (Kennedy, J., dissenting) (The Court's ruling reflects "a faintly disguised distrust of judges and their purported usurpation of the jury's function in criminal trials.").

5 John StuART MilL, ON LIBerTY 151 (Penguin Books 1984) (1859).

- A range of commentators have discussed the distorting influence of legislative politics on criminal lawmaking. See, e.g., William J. Stuntz, The Pathological Politics of Criminal Law, 100 Mich. L. Rev. 505 (2001); Douglas A. Berman, A Common Law For This Age of Federal Sentencing: The Opportunity and Need For Judicial Lawmaking, 11 STAN. L. \& PoL'Y Rev. 93, 107-O9 (1999); Ronald F. Wright, Three Strikes Legislation and Sentencing Commission Objectives, 20 LAW \& POL'Y 429, 437 (1998).

7 The Court's ruling in Blakely was ostensibly grounded on the Sixth Amendment right to a jury trial. See Blakely, $124 \mathrm{~S}$. Ct. at 2538 (holding that the state sentencing scheme "did not comply with the Sixth Amendment."). In my view, the line of cases makes more sense when understood as an expression of Due Process values. See Jones v. United States, 526 U.S. 227, 243 n.6 (1999) (Souter, J.) (emphasizing that the principles underlying the Court's ruling reflects both Sixth Amendment and Due Process values); Apprendi, 530 U.S. at 477 (stressing that the rights at stake include "constitutional protections of surpassing importance," including the "due process of law"). At the very least, Due Process values color the interpretation of the Sixth Amendment in these cases.

8 See, e.g., Cruzan v. Dir., Mo. Dep't of Health, 497 U.S. 261, 279 (1990) ("' [W] hether respondent's constitutional rights have been violated must be determined by balancing his liberty interests against the relevant state interests.'") (internal citations omitted); Poe v. UIIman, 367 U.S. 497, 542 (1961) (Harlan, J., dissenting) (Due Process "has represented the balance which our Nation, built upon postulates of respect for the liberty of the individual, has struck between that liberty and the demands of organized society").

9 This is not to suggest that the legislature lacks redeeming characteristics. Sentencing decisions, for example, require complex judgments about policy, and the legislature is arguably better suited to make those judgments than any other branch. As a result, concerns about legislative abuse must be balanced against an awareness of the legislature's institutional advantages. Nonetheless, some degree of skepticism about the legislature must be assumed if we are to make sense of the Court's decisions in Apprendi and Blakely. After all, if one thought that the legislature poses a minimal danger to individual liberty, then the procedural protections announced in those cases makes little sense Finally, it is worth emphasizing that nothing in these cases prevents the legislature from enacting sentencing rules. The decisions only call for special procedural safeguards if the legislature chooses to do so.

10 In state systems where judges are appointed or elected to fixed terms, one might expect a reduced degree of judicial independence. In these states, greater skepticism of judicial sentencing decisions may be warranted, though arguably not to the point of imposing the same procedural restrictions on the judiciary as are applied to the legislature. In New Jersey, the jurisdiction in Apprendi, judges serve an initial seven-year term and then can be appointed by the governor to life tenure. See N.J. CoNST. art. VI. In Washington State, the jurisdiction in Blakely, Supreme Court judges must stand for reelection every six years. WASH. REV. CODE ANN. $\S 2.04 .071$ (2004).

11 Alexander Hamilton observed that the institutional structure of the judiciary - life tenure, protected salaries - serves to insulate the judiciary from majority will and make it a natural defender of individual liberty. See, e.g., The Federalist No. 78 (Alexander Hamilton) ("This independence of judges is equally requisite to guard the Constitution and the rights of individuals from the effects of those ill humors which the arts of designing men, or the influence of particular conjectures, sometimes disseminate among the people themselves ...").

12. At the same time, it is a mistake to ignore the potential shortcomings of the judiciary. Judicial sentencing decisions can be deeply flawed. A judge can impose a sentence that is based on discriminatory or arbitrary considerations. She can increase a sentence based on evidence of dubious validity (under a preponderance standard). She can be sensitive to political pressures just like the legislature, especially if the judge is an elected official. See infra n.10. If those concerns are found to be significant, the Court may ultimately decide to extend procedural protections to certain sentencing decisions by the judiciary, as well.

13 See Duncan v. Louisiana, 391 U.S. 145, 151 (1968) (quoting W. Blackstone, CommentaRies on the LaWS OF England 349 (T. Cooley ed. 1899)) (the grand and petit juries represent a "strong and two-fold barrier... between the liberties of the people and the prerogative of the [government]." "); Jones, 526 U.S. at 245 (Souter, J.) (“The potential or inevitable severity of sentences was indirectly checked by juries' assertions of a mitigating power when the circumstances of a prosecution pointed to political abuse of the criminal process or endowed a criminal conviction with particularly sanguinary consequences."). See also United States $v$. Khan, 325 F. Supp. $2 d 218 * 33$ (E.D.N.Y. 2004) (Weinstein, J.) (The jury "expresses the view of a sometime compassionate free people faced.with an individual miscreant in all his or her tainted humanity, as opposed to the abstract cruelties of a more theoretical and doctrinaire distant representative government."). For a perceptive analysis of the jury's role in 
protecting individual liberty, see Rachel Barkow, Recharging the Jury: the Criminal Jury's Constitutional Role in an Era of Mandatory Sentencing, 152 U. PA. L. REv. 33 (2003).

14 See Barkow, supra note 13, at 64 . In theory, judges can also serve this role. However, good reasons may exist to believe that a jury is more likely than a judge to disobey or nullify an excessively severe sentencing statute. See, e.g., id. at 61 (A jury "does not need to give any reason for an acquittal, and it faces no review by a court or legislature. It therefore has a greater opportunity than a judge to check the state and these general punitive laws.").

15 Harris v. United States, 536 U.S. 545, 577-78 (2002)

(Thomas, J. dissenting) ("As a matter of common sense, an increased mandatory minimum heightens the loss of liberty and represents the increased stigma society attaches to the offense. Consequently, facts that trigger an increased mandatory minimum sentence warrant constitutional safeguards."); Apprendi, 530 U.S. at 563 (Breyer, J. dissenting) (" $[A]$ s a practical matter, a legislated mandatory 'minimum' is far more important to an actual defendant" than any maxima.)

16 Reversing Harris would not necessarily lead to less severe minimum sentences. A legislature might respond to such a decision by eliminating specific mandatory statutes, while raising sentences across the board. Thus, rather than establishing mandatory minimum sentences for drug transactions involving a specified amount of drugs, the legislature might simply raise the minimum sentence for all drug offenses regardless of drug amount.

At the same time, if Harris is overturned, the legislature would face certain constraints in taking such evasive action. Notably, in a post.Harris world, any fact that increases a statutory minimum must be proved beyond a reasonable doubt at trial. If the legislature increases sentences across the board, the jury might then refuse to convict. The increased risk of jury nullification might discourage the legislature from raising sentences excessively.

Nonetheless, if this check on legislature overreaching proves ineffective, the Court may need to adopt additional remedial steps. Various options might be imagined, from substantive scrutiny of mandatory minimum statutes to permitting courts to disclose the mandatory minimum sentence to the jury, further encouraging the jury to serve as a counterweight to legislative abuse.

17 See Douglas Berman, Formalism Meets Functionality: An Ohio Case Study (Saturday, August 28, 2004), in Sentencing Law and Policy Blog, at http://sentencing.typepad.com (last visited September 6, 2004).

is See, e.g., Jeffrey S. Parker \& Michael K. Block, The Limits of Federal Criminal Sentencing Policy; Or, Confessions of Two Reformed Reformers, 9 GEo. MASON L. REv. 1001, 1008, 1019 (2001) (" $[T]$ he 1989 amendments to the robbery and fraud guidelines both involved gratuitous increases in punishment levels that had no basis in either principle or practice, and instead were essentially political decisions reflecting responses to interest group pressures."). See generally Aaron J. Rappaport, Unprincipled Punishment: The U.S. Sentencing Commission's Troubling Silence about the Purposes of Punishment, 6 Buff. CrIM. L. R. 1043 (2003).

19 See Steven C. Chanenson, Hoist With Their Own Petard?, 17 Fed. Sent. Rep. 20 (2004).

20 Prosecutorial Remedies and Tools Against the Exploitation of Children Today Act of 2003, Pub. L. No. 108-21.

21 Chanenson, supra note 19.

22 Id.

${ }^{23}$ Such a ruling would not contravene the Court's decision in Mistretta, where the Court held that the Sentencing Commission was an independent body situated in the judicial branch. As a formal matter, that case involved a Separation of Powers challenge, not a Due Process or Sixth Amendment issue. Moreover, Mistretta was decided before the Guidelines became fully operational. Evidence of the Guidelines' operation over the past 18 years has raised questions about the Supreme Court's prediction that the Commission would serve as a neutral voice of sentencing policy. Moreover, recent statutory changes pursuant to the PROTECT Act have raised further questions about the Commission's independence. Thus, even if Mistretta were relevant to this case, "changed facts" would justify the reconsideration of the ruling as binding precedent. See Planned Parenthood v. Casey, 505 U.S. 833, 855 (1992) (observing that precedent can be overruled when "facts have so changed, or come to be seen so differently, as to have robbed the old rule of significant application or justification."). 